\title{
Role of pseudolaric acid B in A549 lung cancer cell proliferation and apoptosis
}

\author{
TINGTING GUAN and YANMIN YANG
}

\begin{abstract}
Department of Geriatrics, Shengjing Hospital of China Medical University, Shenyang, Liaoning 110004, P.R. China
\end{abstract}
Received March 27, 2013; Accepted October 9, 2013

DOI: $10.3892 / \mathrm{mmr} .2013 .1800$

\begin{abstract}
Recently, traditional Chinese medicine has gained attention for its potential use as a chemotherapeutic agent. Pseudolaric acid B (PAB) is a diterpene acid isolated from Pseudolarix kaempferi and possesses antifungal, antimicrobial, antifertility and antiangiogenic properties. It was also reported that PAB may inhibit proliferation and induce apoptosis in various types of cancer. However, its effects on A549 lung cancer cells remain to be determined. The present study aimed to determine the potential roles of PAB in the proliferation and apoptosis of A549 cells. The results showed that PAB inhibited A549 cell proliferation in a time- and dose-dependent manner. Fluorescence microscopy results showed that cells treated with $20 \mu \mathrm{mol} / 1 \mathrm{PAB}$ for $24 \mathrm{~h}$ exhibited karyorrhexis and apoptotic body formation. In addition, A549 cells were treated with 5, 10, 20, 40 or $80 \mu \mathrm{mol} / 1 \mathrm{PAB}$ for $24 \mathrm{~h}$ and apoptosis was analyzed using Annexin-V/propidium iodide kit. The apoptosis rates were 8.95, 18.71, 24.66, 35.02 and $43.64 \%$, respectively, in PAB-treated cells and $0.80 \%$ in the control group. Furthermore, western blot analysis showed that PAB treatment upregulated the protein levels of Bax, Bad and downregulated Bcl-2 and Bcl-xl expression. In conclusion, PAB may serve as a potent chemotherapeutic agent against human lung cancer.
\end{abstract}

\section{Introduction}

Lung cancer is one of the most prevalent types of cancers worldwide and is the leading cause of cancer-related mortalities. Based on the GLOBOCAN 2008 estimates, lung cancer was the leading type of cancer in males, comprising $17 \%$ of total novel cancer cases and $23 \%$ of total cancer-related mortalities. The mortality rate for lung cancer among females in developing countries accounts for $11 \%$ of the total female cancer-related mortalities, second to breast cancer (1). To date,

Correspondence to: Dr Yanmin Yang, Department of Geriatrics, Shengjing Hospital of China Medical University, 36 Sanhao Street, Shenyang, Liaoning 110004, P.R. China

E-mail: monya.sunshine@yahoo.com.cn

Key words: pseudolaric acid B, A549 lung cancer cell, apoptosis surgery, radiotherapy and chemotherapy are the predominant treatment strategies for lung cancer; however, the efficacy of these therapies is limited and may result in a number of side effects. Over the past decade, the mortality rates of lung cancer remain high, with the 5 -year survival rate $<15 \%$ (2). Therefore, investigating novel therapeutic targets is a demanding task.

In previous years, traditional Chinese medicine has drawn great attention for use as chemotherapeutic agents against malignant tumors. Traditional Chinese medicines have a number of advantages, including fewer side effects and combination treatment to increase efficiency $(3,4)$. Diterpene acid is one of the numerous traditional Chinese medicines that has a long history of recordation and clinical application (5). Diterpene acid has antiviral, anti-inflammatory, antitumor, antifungal and immunosuppressive effects (6-9). Pseudolaric acid B (PAB; Fig. 1) is a diterpene acid isolated from the root and trunk bark of Pseudolarix kaempferi and possesses multiple biological and pharmacological activities, including antifungal, antifertility, antitumor, anti-inflammatory and anti-angiogenic properties (10-15).

The antitumor effect of PAB has been confirmed in multiple cancer cell lines. In human HeLa cervical carcinoma cells, PAB promotes apoptosis via activating c-Jun N-terminal kinases (JNK), protein kinase $\mathrm{C}$ (PKC) and caspase-3, downregulating extracellular signal-regulated kinases (ERK) and Bcl-2 as well as upregulates the P53 and Bax proteins $(16,17)$. In human melanoma A375-S2 cells, PAB inhibits proliferation and induces apoptosis by arresting the cell cycle at the G2/M checkpoint, upregulating P53 and Bax levels and downregulating expression of Bcl-2 and $\mathrm{Bcl}-\mathrm{xl}$ proteins (18). In human AGS gastric cancer cells, PAB inhibits cell growth in a time- and dose-dependent manner by arresting the cells at the $\mathrm{G} 2 / \mathrm{M}$ phase, downregulating the $\mathrm{CDC} 2$ and $\mathrm{Bcl}-2$ proteins and activating caspase-3 (19). In Bel-7402 human hepatocellular carcinoma cells, PAB induces apoptosis through caspase- 3 activation and cell cycle inhibition at the G2/M phase (20). In MDA-MB-468 human breast cancer cells, PAB inhibits cell growth by downregulating the hypoxia inducible factor-1 $\alpha$ protein (15). In MCF-7 human breast cancer cells, PAB induced apoptosis by activating JNK, inactivating ERK and upregulating P21 and P53 protein expression $(21,22)$. In murine fibrosarcoma L929 cells, PAB promotes proliferation, inhibits apoptosis and arrests the cell cycle at the $\mathrm{G} 2 / \mathrm{M}$ phase by downregulating the $\mathrm{Bcl}-2$ and $\mathrm{CDC} 2$ proteins $(23,24)$. In HL-60 human leukemia cells, PAB inhibits proliferation 
and induces apoptosis by arresting cells at the G2/M phase of the cell cycle and activating of caspase-3 (25). In DU145 hormone-refractory prostate cancer cells, PAB induced apoptosis by activating caspase-3 and -9 and downregulating Bcl-2 (26). In U87 glioblastoma cells, PAB inhibits proliferation and induces apoptosis by arresting cell cycle at the G2/M phase, activating caspase-3, upregulating P53 and Bax protein and downregulating Bcl-2 (27).

However, there have been no studies concerning the antitumor effect of PAB in A549 human lung cancer cells. In the present study, the potential roles of $\mathrm{PAB}$ in proliferation and apoptosis in A549 lung cancer cells were investigated.

\section{Materials and methods}

Reagents. PseudolaricacidB(PAB,productno.110880-200502), which was purchased from Liaoning North Yaojian Technology and Developing Company (Liaoning, China), was dissolved in dimethylsulfoxide (DMSO) and stored at $-20^{\circ} \mathrm{C}$.

Cell culture. The A549 human lung cancer cell line was purchased from the American Type Culture Collection (Manassas, VA, USA) and cultured in RPMI-1640 medium (Gibco-BRL, Carlsbad, CA, USA) supplemented with $10 \%$ fetal calf serum (Solarbio Science and Technology, Beijing, China). Cells were cultured in a $37^{\circ} \mathrm{C}, 5 \% \mathrm{CO}_{2} / 95 \%$ air environment. The medium was changed everyday and the cells were digested using $0.25 \%$ trypsin.

MTT assay. A549 cells (1.0x10\%/well) were plated in 96-well plates and cultured overnight. Cells were incubated with 0,5 , $10,20,40$ and $80 \mu \mathrm{mol} / 1 \mathrm{PAB}$ for 24,48 and $72 \mathrm{~h}$, respectively. Briefly, $10 \mu \mathrm{l}$ of $5 \mathrm{mg} / \mathrm{ml}$ MTT (Sigma, St. Louis, MO, USA) solution was added to each well and incubated for $4 \mathrm{~h}$ at $37^{\circ} \mathrm{C}$, then the supernatant was removed and DMSO (100 $\mu \mathrm{l})$ was added to dissolve the formazan crystals. Absorbance was measured at $570 \mathrm{~nm}$ with an enzyme-linked immunosorbent assay plate reader (Model 550, Bio-Rad, Hercules, CA USA). The experiment was repeated three times.

Assessment of morphological changes. A549 cells $\left(5.0 \times 10^{5}\right)$ were seeded on slides in a 6-well plate and cultured overnight. The cells were treated with $0.20 \mu \mathrm{mol} / 1 \mathrm{PAB}$ and incubated at $37.0^{\circ} \mathrm{C}$ and $5 \% \mathrm{CO}_{2}$ for $24 \mathrm{~h}$. Cells were washed with cold phosphate-buffered saline (PBS) twice, fixed with methanol and glacial acetic acid (3:1) for $15 \mathrm{~min}$ and stained with Hoechst 33342 for $30 \mathrm{~min}$ (Sigma). Morphological changes were observed using fluorescence microscopy (Nikon, Tokyo, Japan).

Assessment of apoptosis. Cells were treated with various concentrations of PAB $(0,5,10,20,40$ and $80 \mu \mathrm{mol} / \mathrm{l})$ and incubated at $37.0^{\circ} \mathrm{C}$ and $5 \% \mathrm{CO}_{2}$ overnight. Cells were collected, centrifuged at $155 \mathrm{x}$ g for $5 \mathrm{~min}$, washed twice with cold PBS and resuspended using $1 \mathrm{X}$ binding buffer, producing a final concentration of $1.0 \times 10^{6}$ cells $/ \mathrm{ml}$. Suspension buffer $(100 \mu \mathrm{l})$ was transferred to a test tube, $5 \mu \mathrm{l}$ Annexin V-fluorescein isothiocyanate (FITC) and $10 \mu \mathrm{l}$ propidium iodide (PI) were added and mixed. Following $15 \mathrm{~min}$ staining at room temperature, another $400 \mu 1 \mathrm{X}$ binding buffer was added. Cell

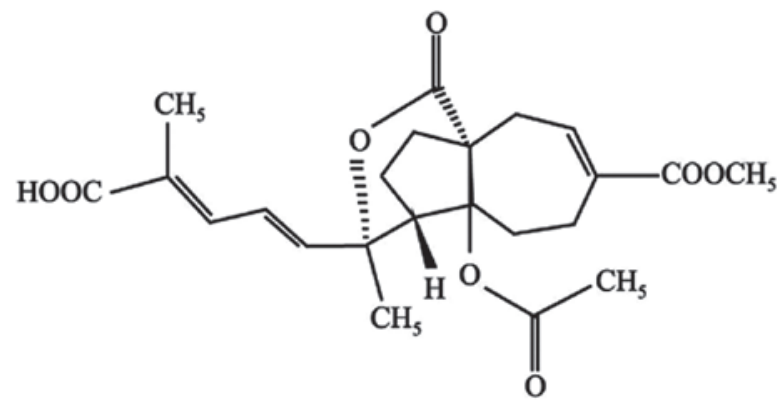

Figure 1. Chemical structural of pseudolaric acid B.

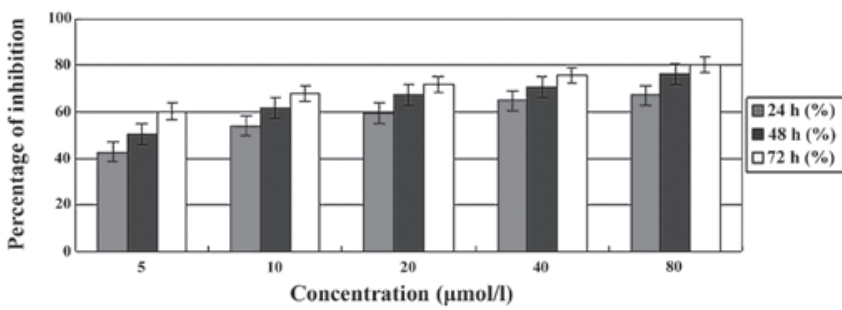

Figure 2. A549 cells were incubated with $0,5,10,20,40$ and $80 \mu \mathrm{mol} / 1 \mathrm{PAB}$ for 24,48 and $72 \mathrm{~h}$ respectively. The cell growth inhibition ratio increased with $\mathrm{PAB}$ concentration and incubation time. The ratio was determined by an MTT assay. ( $\mathrm{P}<0.05$, vs. control).PAB, pseudolaric acid B
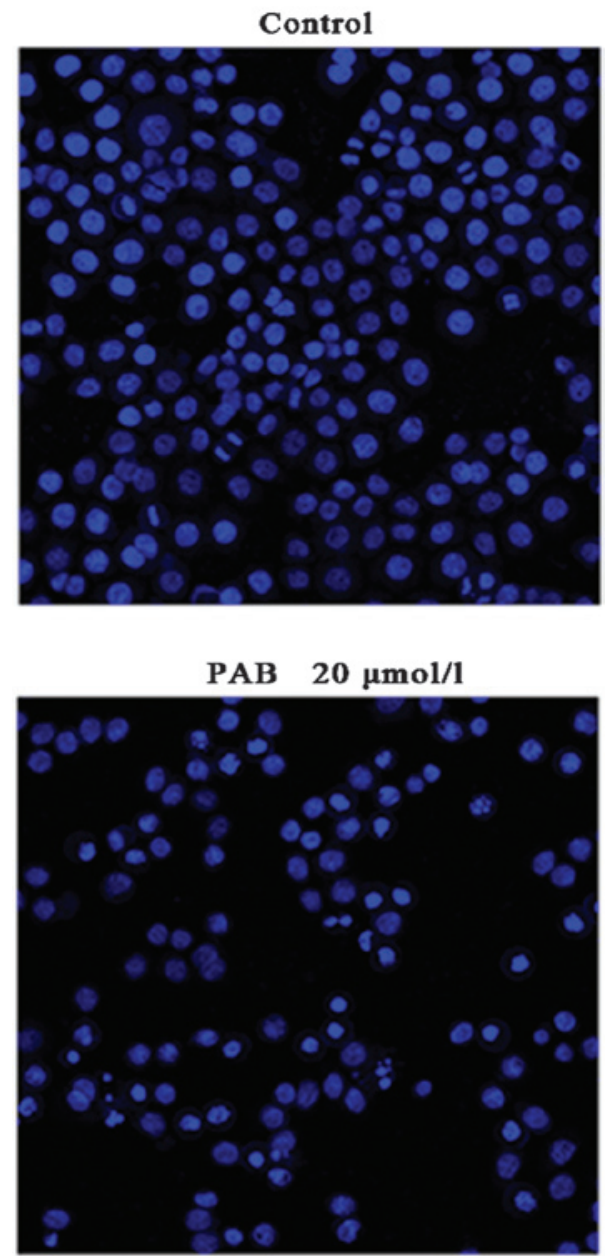

Figure 3. A549 cells treated with $20 \mu \mathrm{mol} / 1$ PAB for $24 \mathrm{~h}$ exhibited karyorrhexis and apoptotic body formation by Hoechst 33342 staining. PAB, pseudolaric acid B 
A
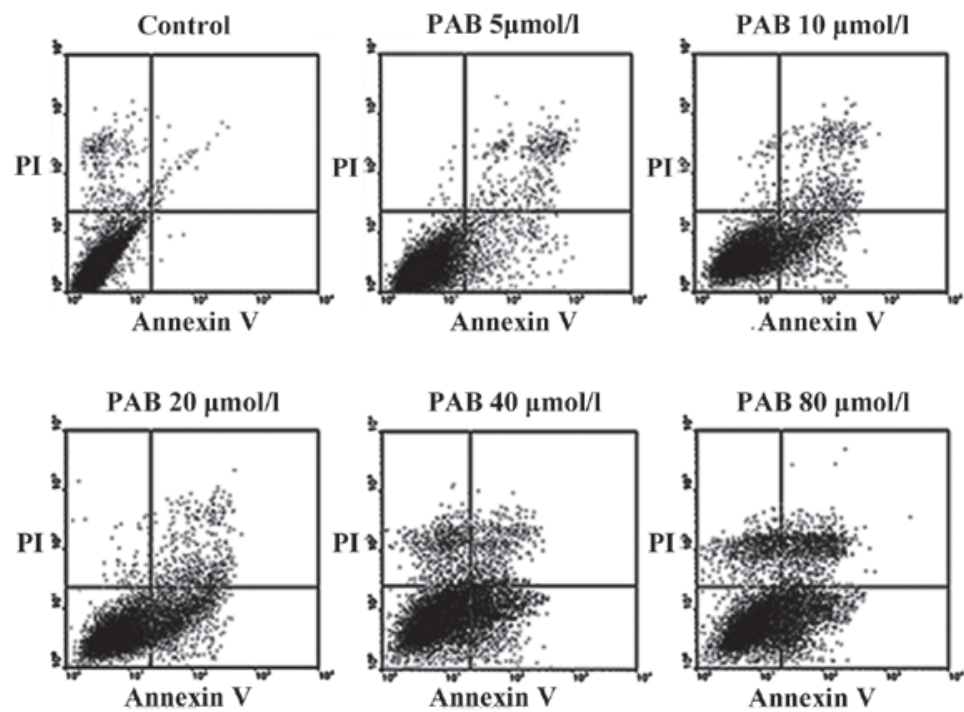

B

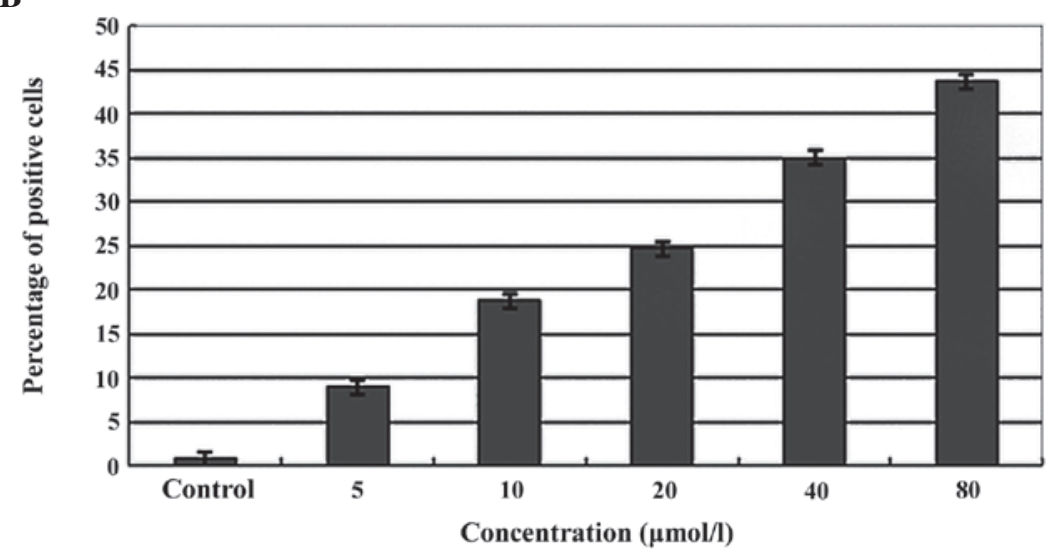

Figure 4. (A) A549 cells were treated with 5, 10, 20, 40 or $80 \mu \mathrm{mol} / 1 \mathrm{PAB}$ for $24 \mathrm{~h}$ and apoptosis was analyzed using an Annexin-V/propidium iodide kit. (B) Histograms express apoptosis data. $(\mathrm{P}<0.05$, vs. control). PAB, pseudolaric acid B.

apoptosis was examined using a BD FACScan flow cytometry system (Franklin Lakes, NJ, USA).

Western blot analysis. Cells were treated with 0, 5, 20 and $80 \mu \mathrm{mol} / 1 \mathrm{PAB}$ solution for $24 \mathrm{~h}$. The cells were then harvested (cell number, $>5 \times 10^{6} / \mathrm{ml}$ ) and washed twice with cold PBS. Western blot analysis was performed. Briefly, the cell pellets were resuspended in lysis buffer at $4^{\circ} \mathrm{C}$ for $1 \mathrm{~h}$. Following centrifugation at $22,378 \mathrm{x}$ g for $20 \mathrm{~min}(2 \mathrm{~K} 15 \mathrm{C}$, Sigma), the supernatant was collected and stored at $-80^{\circ} \mathrm{C}$. A total of $40 \mu \mathrm{g}$ protein was separated using $10 \%$ SDS-PAGE and transferred to a polyvinylidene fluoride membrane (Millipore, Bedford, MA, USA). The membrane was blocked with $5 \%$ non-fat milk and incubated overnight at $4^{\circ} \mathrm{C}$ with antibodies against Bcl-2 (1:500), Bcl-xl (1:500), Bax (1:1,000), Bad (1:1,000) (all Cell Signaling Technology, Inc., Beverly, MA, USA) and $\beta$-actin (1:500; Santa Cruz Biotechnology, Inc., Santa Cruz, CA, USA). Following incubation with horseradish peroxidase-conjugated anti-mouse IgG (Santa Cruz Biotechnology, Inc.) at $37^{\circ} \mathrm{C}$ for $2 \mathrm{~h}$, proteins were visualized using enhanced chemiluminescence (Pierce Biotechnology Inc., Rockford, IL, USA) and detected using BioImaging Systems (UVP Inc., Upland, CA, USA).

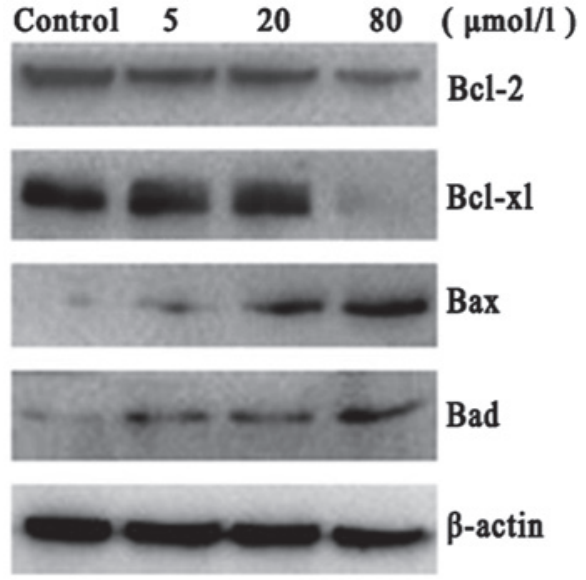

Figure 5. A549 cells treated with 0, 5, 20 and $80 \mu \mathrm{mol} / 1 \mathrm{PAB}$ solution respectively for $24 \mathrm{~h}$. PAB treatment upregulated the protein levels of Bax and Bad and downregulated $\mathrm{Bcl}-2$ and $\mathrm{Bcl}-\mathrm{xl}$ expression. PAB, pseudolaric acid B.

Statistical analysis. The statistical package SPSS version 11.0 (SPSS, Chicago, IL, USA) was used for all analysis. All values are expressed as the mean \pm standard deviation. Differences between groups were compared with Student's t-test and 
$\mathrm{P}<0.05$ was considered to indicate a statistically significant difference.

\section{Results}

Effect of PAB on proliferation of A549 lung cancer cells. To detect the effect of PAB on the proliferation of A549 cells, the cells were treated with different doses of PAB ranging from $0,5,10,20,40$ and $80 \mu \mathrm{mol} / 1$ for the indicated times ( 24,48 or $72 \mathrm{~h}$ ). The cell growth inhibition ratio was observed to increase with the PAB concentration and incubation time (Fig. 2), suggesting that PAB significantly inhibits A549 cell growth in a dose- and time-dependent manner.

Effect of PAB on A549 cell morphology. Morphological changes were observed using fluorescence microscopy (Nikon). A549 cells treated with $20 \mu \mathrm{mol} / 1 \mathrm{PAB}$ for $24 \mathrm{~h}$ were stained with Hoechst 33342. Cells treated with $20 \mu \mathrm{mol} / \mathrm{l} \mathrm{PAB}$ for $24 \mathrm{~h}$ exhibited karyorrhexis and apoptotic body formation following Hoechst 33342 staining (Fig. 3). Morphologically, PAB is capable of inducing apoptosis in A549 cells.

Effect of PAB on A549 cell apoptosis. A549 cells were treated with varying concentrations of $\operatorname{PAB}(0,5,10,20,40$ and $80 \mu \mathrm{mol} / \mathrm{l})$ overnight. The cells were stained with an Annexin-V/PI kit and cell apoptosis was examined using BD flow cytometry. The apoptosis rates were 8.95, 18.71, 24.66, 35.02 and $43.64 \%$, respectively, in PAB treatment cells and the rate was $0.80 \%$ in the control cells without $\mathrm{PAB}$ treatment. These results suggested that PAB induces A549 cell apoptosis (Fig. 4).

Effect of PAB on the protein levels of Bcl-2, Bcl-xl, Bax and $B a d$. To further investigate the mechanism of PAB-induced apoptosis, the protein levels of a number of $\mathrm{Bcl}-2$ family members were examined. Bax and Bad protein levels were observed to increase and $\mathrm{Bcl}-2$ and $\mathrm{Bcl}-\mathrm{xl}$ protein levels were decreased following PAB treatment. These results indicated that, at the molecular level, PAB induces A549 cell apoptosis by regulating Bcl-2, Bcl-xl, Bax and Bad (Fig. 5).

\section{Discussion}

The therapeutic potential of traditional Chinese medicine has been increasingly recognized by oncologists $(3,4)$. PAB is a diterpene acid isolated from the root and trunk bark of Pseudolarix kaempferi and possesses multiple biological and pharmacological activities, including antifungal, antimicrobial, antifertility and antiangiogenic properties (10-15). It has been previously confirmed that PAB exhibits an antitumor effect by inducing apoptosis in various types of cancer (16-27). Apoptosis is important in homeostasis maintenance through a balance between cell proliferation and cell death (28). It is well established that cell apoptosis is closely associated with cancer development and progression (29). The antitumor effects of a number of traditional Chinese medicines are based on their ability to induce apoptosis $(30,31)$.

Bcl-2 family members are apoptosis regulators. Bcl-2 and Bcl-xl inhibit apoptosis while Bax and Bad promote apoptosis (32). It is reported that a number of traditional Chinese medicines exhibit their antitumor effects by simultaneous upregulation of Bax and Bad and downregulation of Bcl-2 and Bcl-xl (33-35).

In the present study, the effect of $\mathrm{PAB}$ on the proliferation of A549 cells was examined and it was observed that PAB significantly inhibits A549 cell growth in a time- and dose-dependent manner. In addition, the morphological changes induced by $\mathrm{PAB}$ were determined and it was identified karyorrhexis and apoptotic body formation following PAB treatment. Furthermore, the apoptosis rate using Annexin-V/PI staining was investigated and it was observed that PAB induced A549 apoptosis in a dose-dependent manner. Finally, the potential mechanisms by which PAB induces apoptosis at molecular levels were investigated and PAB was identified to upregulate pro-apoptosis $\mathrm{Bax}$ and Bad proteins and downregulate pro-survival Bcl-2 and Bcl-xl proteins.

In conclusion, PAB was shown to inhibit A549 cell proliferation in a time and dose-dependent manner. PAB induced apoptosis by the upregulation of Bax and Bad and downregulation of Bcl-2 and Bcl-xl. Thus, PAB may serve as a potent chemotherapeutic agent against human lung cancer.

\section{References}

1. Jemal A, Bray F, Center MM, et al: Global cancer statistics. CA Cancer J Clin 61: 69-90, 2011.

2. Erridge SC, Møller H, Price A and Brewster D: International comparisons of survival from lung cancer: pitfalls and warnings. Nat Clin Pract Oncol 4: 570-577, 2007.

3. Efferth T, Li PC, Konkimalla VS and Kaina B: From traditional Chinese medicine to rational cancer therapy. Trends Mol Med 13: 353-361, 2007.

4. Harvey AL: Natural products in drug discovery. Drug Discov Today 13: 894-901, 2008.

5. Hanson JR: Diterpenoids. Nat Product Rep 26: 1156-1171, 2009.

6. Cheng SY, Chuang CT, Wang SK, et al: Antiviral and anti-inflammatory diterpenoids from the soft coral Sinularia gyrosa. J Nat Prod 73: 1184-1187, 2010.

7. Hsieh TC, Wijeratne EK, Liang JY, et al: Differential control of growth, cell cycle progression, and expression of NF-kappa B in human breast cancer cells MCF-7, MCF-10A, and MDA-MB-231 by ponicidin and oridonin, diterpenoids from the chinese herb Rabdosia rubescens. Biochem Biophys Res Commun 337: 224-231, 2005.

8. Yang SP, Dong L, Wang Y, et al: Antifungal diterpenoids of Pseudolarix kaempferi, and their structure-activity relationship study. Bioorg Med Chem 11: 4577-4584, 2003.

9. Duan HQ, Takaishi Y, Momota H, et al: Immunosuppressive diterpenoids from Tripterygium wilfordii. J Nat Prod 62: 1522-1525, 1999.

10. Trost BM, Waser $\mathbf{J}$ and Meyer A: Total synthesis of (-)-pseudolaric acid B. J Am Chem Soc 130: 16424-16434, 2008.

11. Li E, Clark AM and Hufford CD: Antifungal evaluation of pseudolaric acid B, a major constituent of Pseudolarix kaempferi. J Nat Prod 58: 57-67, 1995.

12. Liu B, Chen H, Lei ZY, Yu PF and Xiong B: Studies on anti-tumour activities of pseudolaric acid-B (PLAB) and its mechanism of action. J Asian Nat Prod Res 8: 241-252, 2006.

13. Li T, Wong VK, Yi XQ, et al: Pseudolaric acid B suppresses $\mathrm{T}$ lymphocyte activation through inhibition of NF-kappa B signaling pathway and p38 phosphorylation. J Cell Biochem 108: 87-95, 2009.

14. Meng AG and Jiang LL: Pseudolaric acid B-induced apoptosis through p53-dependent pathway in human gastric carcinoma cells. J Asian Nat Prod Res 11: 142-152, 2009.

15. Li MH, Miao ZH, Tan WF, et al: Pseudolaric acid B inhibits angiogenesis and reduces hypoxia-inducible factor lalpha by promoting proteasome-mediated degradation. Clin Cancer Res 10: 8266-8274, 2004.

16. Gong XF, Wang MW, Wu Z, et al: Pseudolaric acid B induces apoptosis via activation of c-Jun N-terminal kinase and caspase-3 in HeLa cells. Exp Mol Med 36: 551-556, 2004. 
17. Gong XF, Wang MW, Tashiro S, et al: Involvement of JNK-initiated p53 accumulation and phosphorylation of p53 in pseudolaric acid B induced cell death. Exp Mol Med 38: 428-434, 2006.

18. Gong XF, Wang MW, Tashiro S, et al: Pseudolaric acid B induces apoptosis through $\mathrm{p} 53$ and $\mathrm{Bax} / \mathrm{Bcl}-2$ pathways in human melanoma A375-S2 cells. Arch Pharm Res 28: 68-72, 2005.

19. Li KS, Gu XF, Li P, et al: Effect of pseudolaric acid B on gastric cancer cells: inhibition of proliferation and induction of apoptosis. World J Gastroenterol 11: 7555-7559, 2005.

20. Wu WY, Guo HZ, Qu GQ, et al: Mechanisms of pseudolaric acid B-induced apoptosis in Bel-7402 cell lines. Am J Chin Med 34: 887-899, 2006

21. Yu JH, Cui Q, Jiang YY, et al: Pseudolaric acid B induces apoptosis, senescence, and mitotic arrest in human breast cancer MCF-7. Acta Pharmacol Sin 28: 1975-1983, 2007.

22. Yu JH, Wang HJ, Li XR, et al: Protein tyrosine kinase, JNK, and ERK involvement in pseudolaric acid B-induced apoptosis of human breast cancer MCF-7 cells. Acta Pharmacol Sin 29: 1069-1076, 2008.

23. Yu J, Li X, Tashiro S, et al: Bcl-2 family proteins were involved in pseudolaric acid B-induced autophagy in murine fibrosarcoma L929 cells. J Pharmacol Sci 107: 295-302, 2008.

24. Qi M, Yao G, Fan S, et al: Pseudolaric acid B induces mitotic catastrophe followed by apoptotic cell death in murine fibrosarcoma L929 cells. Eur J Pharmacol 683: 16-26, 2012.

25. Ma G, Chong L, Li XC, et al: Selective inhibition of human leukemia cell growth and induction of cell cycle arrest and apoptosis by pseudolaric acid B. J Cancer Res Clin Oncol 136: 1333-1340, 2010.
26. Zhao D,Lin F, Wu X, et al: Pseudolaric acid B induces apoptosis via proteasome-mediated Bcl-2 degradation in hormone-refractory prostate cancer DU145 cells. Toxicol In Vitro 26: 595-602, 2012.

27. Khan M, Zheng B, Yi F, et al: Pseudolaric acid B induces caspase-dependent and caspase-independent apoptosis in U87 glioblastoma cells. Evid Based Complement Alternat Med 2012: 957568,2012

28. Thompson CB: Apoptosis in the pathogenesis and treatment of disease. Science 267: 1456-1462, 1995

29. Lowe SW and Lin AW: Apoptosis in cancer. Carcinogenesis 21: 485-495, 2000

30. Huang DM, Shen YC, Wu C, et al: Investigation of extrinsic and intrinsic apoptosis pathways of new clerodane diterpenoids in human prostate cancer PC-3 cells. Eur J Pharmacol 503: 17-24, 2004.

31. Cheung HY, Cheung SH, Li JL, et al: Andrographolide isolated from Andrographis paniculata induces cell cycle arrest and mitochondrial-mediated apoptosis in human leukemic HL-60 cells. Planta Med 71: 1106-1111, 2005.

32. Korsmeyer SJ: BCL-2 gene family and the regulation of programmed cell death. Cancer Res 59 (Suppl 7): 1693s-1700s, 1999.

33. Jiao Y, Ge CM, Meng QH, et al: Dihydroartemisinin is an inhibitor of ovarian cancer cell growth. Acta Pharmacol Sin 28: 1045-1056, 2007.

34. Wang JB, Qi LL, Zheng SD and Wu TX: Curcumin induces apoptosis through the mitochondria-mediated apoptotic pathway in HT-29 cells. J Zhejiang Univ Sci B 10: 93-102, 2009.

35. Wu SJ, Ng LT, Lin DL, et al: Physalis peruviana extract induces apoptosis in human Hep G2 cells through CD95/CD95L system and the mitochondrial signaling transduction pathway. Cancer Lett 215: 199-208, 2004. 